POLICY-MAKING FOR SYDNEY'S AIRPORT NEEDS: A Comparative and Historical Perspective

Will Sanders

URU Working Paper No. 20

December 1989

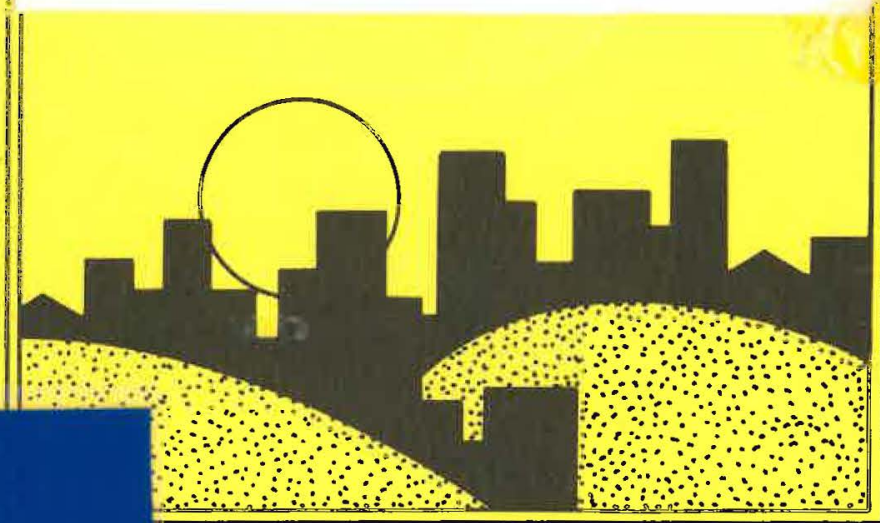

URBAN RESEARCH UNIT

-ESEARCH SCHOOL OF SOCIAL SCIENCES

HANCOCK AUSTRALIAN NATIONAL UNIVERSITY

B'MENT

serial

HT101

.487

$n 0.20$ 


\section{POLICY-MAKING FOR SYDNEY'S AIRPORT NEEDS: A Comparative and \\ Historical Perspective}

Will Sanders

URU Working Paper No. 20

December 1989

SERIES EDITORS:

S. R. Schreiner and C. J. Lloyd

ISBN 0731508270

ISSN $\quad 1030-2921$
Urban Research Unit Research School of Social Sciences Australian National University GPO Box 4 Canberra, ACT, Australia 2601 
(C) Urban Research Unit, Research School of Social Sciences, Australian National University 1989

\section{National Library of Australia}

Cataloguing-in-Publication data:

Sanders, Will, 1956-

Policy-making for Sydney's airport needs.

ISBN 0731508270.

1. Airports - New South Wales - Sydney - Runways. 2. Kingsford-Smith Airport (Sydney, N.S.W.). I. Australian National University. Urban Research Unit. II. Title. (Series : URU working paper, no. 20).

387.7362099441

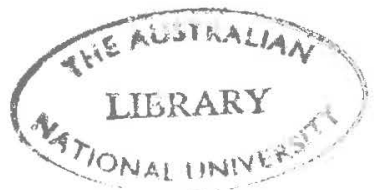




\section{URU WORKING PAPERS}

Established in 1966, the Urban Research Unit carries out studies in the social sciences on Australian cities. Work undertaken in the Unit is multidisciplinary and ranges widely over economic, geographic, historical, sociological, and political aspects of urban and regional structure and development.

URU Working Papers are issued on an occasional basis with the intention of stimulating discussion and making research results quickly and easily available. Most papers will be published in final form elsewhere. In some cases, material will be published which, although of specialist interest, has no ready outlet.

Working Papers represent the work of members of the Unit or papers presented to a URU-sponsored seminar or conference. In most cases, the Working Papers are Australian in content or relevant to the Australian context. Proposed papers are subject to a preliminary internal review of a committee comprising the Series Editors and the Head of Unit. If the review committee deems the papers suitable for possible publication, it is then sent to at least one external assessor for further comment.

The views expressed in these papers are those of the authors and not the Urban Research Unit.

Series Editors:

Shelley R. Schreiner \& Clem Lloyd 
This paper focuses on the decision made by the Hawke government in March 1989 to build a third runway at Sydney (Kingsford Smith) Airport (KSA), subject to normal environmental impact procedures. It notes that this decision was commonly hailed as a policy-making success and that past government procrastination over the construction of a third runway has been conversely seen as policymaking failure. The paper questions these perceptions of failure and success both by recounting the history of policy-making for Sydney's airport needs and by setting the Sydney experience in comparative international perspective. It argues that current congestion at KSA is only in small part a consequence of past government procrastination over runway development and that it is in much larger part a consequence of both unpredicted changes in the various sectors of the aviation industry and a rather passive traffic management and pricing approach adopted by the federal government's aviation authorities. It further argues that in the light of international experience, procrastination over runway development at KSA can be seen for many years to have been a significant policy-making success, and indeed can still be so seen today. One of the current benefits of not having runway construction at KSA nearing completion is that the aviation authorities and aviation industry users in Sydney may be induced to make both more efficient and equitable use of the existing runway facilities at KSA than they have done in the past, particularly during peak hours. 
POLICY-MAKING FOR SYDNEY'S AIRPORT NEEDS:

A Comparative and Historical Perspective ${ }^{1}$

\author{
Will Sanders \\ National Research Fellow \\ Urban Research Unit
}

\title{
INTRODUCTION
}

On 22 March 1989, the Prime Minister Bob Hawke and the Minister for Transport and Communications Ralph Willis announced that the federal Labor government had decided to develop a third runway at Sydney (Kingsford Smith) Airport (KSA), subject to the satisfactory completion of normal environmental impact statement procedures. Proposals for such a runway had been at the centre of debates about Sydney's future airport needs for twenty years. Throughout that period, a third runway at KSA had been strongly advocated by the federal government's aviation authorities and by the aviation industry more generally. Previous federal governments, with the exception of the Fraser Coalition government in late 1982, had baulked at giving support to any third runway plan. Labor governments, in particular, had been sensitive to the criticisms of such a proposal emanating from residents, councillors and parliamentarians in the strongly pro-Labor areas around KSA. Those critics had argued that KSA's adverse impact on the surrounding urban area, particularly through exposure to aircraft noise, was already considerable and should not be increased by the addition of an extra runway. Labor governments had instead preferred the construction of a second airport as the next major step in meeting Sydney's airport needs. Indeed, when the Hawke Labor government came to power in 1983, it did so with a firmly stated commitment to no third runway at KSA. The Hawke government moved quickly to establish a second Sydney airport site selection program in the latter half of 1983 and in February 1986 announced that a second airport site would be acquired at Badgery's Creek in the south-west of the Sydney region. Events appeared to be proceeding fairly smoothly towards Labor's no-third-runway plan until sometime late in 1988.

1 This article has been accepted for publication in the Current Affairs Bulletin. 
With the coming of Australia's bicentennial year and the overseas tourism boom which accompanied it, Sydney's airport facilities became a major focus of public attention and debate in a way they had not been for several years. Calls for the improvement of airport facilities became strident. The Hawke government's initial reaction was to suggest accelerated or 'fast-tracked' development at Badgery's Creek. However, renewed calls for the construction of a third runway became persistent. Aviation industry interests were joined in their advocacy of such a runway by diverse organisations and individuals drawn from the tourism industry, the Sydney business community and country NSW, as well as the Sydney City Council, the newly elected NSW State Coalition government and the federal Coalition opposition. Media commentary was generally in favour of a third runway and advice coming to the federal government from its own aviation authorities was also still strongly of the pro-third runway persuasion. In the end, the weight of interest group, expert bureaucratic and public opinion proved too great for the traditional Labor forces of opposition to the third runway proposal. A reversal of Labor's no-thirdrunway policy was finally effected, though the commitment to a second airport at Badgery's Creek was also retained.

The March Cabinet decision to proceed with a third runway was generally greeted in the media as a significant policy-making success. Rational economic considerations, so the common interpretation ran, had finally triumphed in the policy-making process over irrational political ones. Indeed the Prime Minister and the Minister for Transport and Communications bolstered this interpretation of events by arguing in their media release that the decision 'followed an exhaustive analysis of the economic and aviation policy aspects of all options for meeting Sydney's airport needs' and that this analysis revealed that the 'economically rational option' was 'to build a third runway at KSA subject to an EIS, and proceed with the development of Badgery's Creek but not on a fast track' ${ }^{2}$

Favourable media commentary was, however, also often begrudging in its praise. This derived from the fact that the decision to build a third runway had been so many years in the making. Commentators were wont to point out that expert reports had been calling for the construction of such a

2 Joint Statement From the Prime Minister and the Minister for Transport and Communications, the Hon. Ralph Willis, 22 March 1989, p2. 
runway for over twenty years and that past government procrastination and policy-making failure somewhat marred the present success. But just how much of a failure had past efforts to provide for Sydney's airport needs been? How much was past government procrastination to blame for the congestion which seemed to have reached new proportions at KSA in 1988 and which had sparked this new round of public attention to the airport issue? And just how acute had the need for additional runway capacity at KSA become by the beginning of 1989 ?

My aim in what follows is to explore these questions both by placing the Sydney experience in some degree of comparative international perspective and by drawing on the history of the Sydney case in some greater detail. I will suggest that the present congestion at KSA is only in small part a consequence of past government failure to back the construction of a third runway. It is in much larger part the consequence of some major unpredicted changes in the various sectors of the aviation industry over recent years, both worldwide and in Sydney. Indeed, in the context of these rapidly changing circumstances in the aviation industry, federal government procrastination over the construction of a third runway can be seen for many years to have been a considerable success. I will also suggest that present congestion at KSA is, in part, also a consequence of a rather passive traffic management approach adopted by the federal government's aviation authorities over the years. This traffic management regime, as the federal aviation authorities are now beginning to admit, is inefficient in its allocation of an expensive public resource and is capable of significant amelioration irrespective of the addition of a third runway. Let me elaborate further by discussing developments in the aviation industry and in airport planning, both worldwide and in Sydney, since the beginning of the jet age.

\section{The CoMing of THE JeT Age, UnPRECEDENTED GroWTH AND THE RUSH TO DEVELOP AIRPORTS}

In the late-1950s when jet aircraft were first introduced into the fleets of commercial air carriers around the world, the major challenges for airport policy-makers were to provide longer, stronger runways for the new heavier aircraft and to cope with adverse community reactions to the 
intrusions of jet aircraft noise. In some cities, such as Melbourne, meeting these challenges led to the rapid development of new airports on large greenfield sites on the edges of the metropolitan areas they served. In Sydney, however, as in numerous other cities around the world, these challenges were met at the existing airport. At KSA, a late night curfew was imposed on jet aircraft movements and the existing north/south runway was extended into Botany Bay to the south.

During the 1960s, these two initial problems of airport policy-making in the jet age were joined by another; passenger and aircraft movement numbers began growing at unprecedented and unpredicted rates. In the decade from 1960 to 1970 , passenger movements worldwide virtually trebled, from 106 to 311 million per annum (see Table 1 and Figure 1). In Sydney, they multiplied at a similar rate, from 1.6 to 4.4 million (see Table 3 and Figure 3). Aircraft movement numbers in Sydney during the decade about doubled, from 59,000 in 1960 to 125,000 in 1970 (see Table 4 and Figure 4). The incomplete data presented in Table 2 and Figure 2 suggest that aircraft movement numbers probably also doubled in the $1960 \mathrm{~s}$ worldwide.

Aviation and airport planners of the 1950s had failed to foresee this rapid growth in passenger and aircraft movement numbers during the 1960 s and were caught by surprise. ${ }^{3}$ Making up for their omissions of the previous years, airport planners now began projecting forward the growth rates of the 1960s. Government aviation authorities around the world quickly became convinced of the need to provide major expansions of their airport facilities, including additional runway capacity, by some time in the mid- to late-1970s. Airport construction proposals became commonplace - a fourth airport for New York, a third for London, a second for Montreal and Tokyo and either a second airport or a parallel runway expansion for the existing airport in Toronto, to name a few. 4

3 See Richard De Neufville, Airport Systems Planning: A Critical look at the Methods and Experience, Macmillan, London, 1976, especially chapter 3.

4 See Elliot J. Feldman and Jerome Milch, Technocracy Versus Democracy: The Comparative Politics of International Airports, Boston, Auburn House Publishing Company, 1982 and The Politics of Canadian Airport Development: Lessons for Federalism, Durham, Duke Press, 1983. See also K.J. Radford and M.O. Giesen The Analysis of Conflicts over the Location of Airports Near Major Population Centres, University of Toronto York University Joint Program in Transportation, Research Report No 87, 1984 for details of these cases. 
In the Sydney case, the Sydney Region Outline Plan of 1968 reported the plans of the federal Department of Civil Aviation as being the provision of a third runway at KSA by the mid-to late-1970s, followed by further airport construction at other sites in the region at some time in the $1980 \mathrm{~s}^{5}$ In 1969, a Commonwealth government interdepartmental committee was established to report on Sydney's future commercial airport requirements and in 1970 it recommended that a joint Commonwealth/NSW State government committee be established to advance the matter further. In 1973, this joint committee, led by the Commonwealth government's aviation authorities, sought a decision in principle from the Commonwealth government cabinet to develop a third runway at KSA by the early-1980s. However, the newly-elected Whitlam federal Labor government directed instead that a second airport be developed at Galston in Sydney's north west. This was not a proposal which the aviation authorities or the aviation industry supported, and it was quickly dropped. Airport construction in Sydney was put aside by the federal aviation authorities pending some change in the attitude of their political masters.

This was the sort of equivocation which would lead in later years to much criticism of airport policy-making for Sydney. However, Australian Commonwealth governments were not the only ones to equivocate in the late-1960s and early-1970s. All around the world, resident opposition to the airport construction proposals of the late-1960s and early-1970s was concerted and in a few instances, as in Tokyo, quite violent. Many governments heeded the views of these resident opponents rather than decisively backing the construction plans of their aviation experts. The London, New York and Toronto airport construction proposals of the late1960 s and early-1970s, to name just three, suffered from the same problems of government equivocation and lack of support as did the Sydney proposal. There were, however, other instances, such as in Paris, Montreal and Tokyo, where governments did give decisive support to the construction plans of their aviation authorities of the late-1960s and airport development did go ahead.

5 NSW State Planning Authority, Sydney Region Outline Plan, 1970-2000A.D. A Strategy for Development, Sydney, SPA, March 1968. 
THE OVERPREDICTION OF RUNWAY NEEDS-THE SUCCESS OF NOT BUILDING IN THE 1970S AND EARLY-1980S

During the late-1970s and the early-1980s, the airport construction issue lost much of the urgency it had been accorded in previous years. In Sydney from 1976, the newly-elected Fraser Coalition federal government initiated further inquiries into the city's airport needs through another joint commonwealth/state government committee established in conjunction with the also recently-elected Wran State Labor government. The Fraser government was, however, under little pressure to construct further airport facilities at Sydney and it allowed itself to become entangled in a prolonged standoff over the issue with the NSW State Labor government, at both the political and official levels. While the Fraser Coalition Commonwealth government was generally willing to go along with its aviation authorities' plans for a third runway at KSA, it argued that it could not act without state government support. The State Labor government was of the second airport persuasion and it was not until October 1982 that the federal aviation authorities finally convinced the Fraser Coalition Commonwealth government of the need to proceed unilaterally with a third runway at KSA.

The reason that the Fraser Coalition government could continue for so long to procrastinate over the Sydney airport issue in the late-1970s and early-1980s was that the airport planners of the late-1960s had significantly overpredicted the additional airport facilities, and particularly runways which would be required in these years. As a consequence, when the governments which had backed the construction plans of their aviation authorities in the late-1960s opened their new airports and expansions in the mid-1970s, they often found that these new facilities were very underutilised. Those governments which had equivocated, on the other hand, as in the Sydney case, generally found themselves to be coping quite well. Many airports around the world required new terminals to be built or old ones to be redeveloped in order to cope with new wide bodied aircraft and the larger numbers of passengers which they were carrying. However, few if any airports were short of runway capacity; the critical variable which had led to the new airport and major expansion proposals of a decade before. Indeed, by the late-1970s, there was even something of a positive aversion among governments to building new airports and runways, given the underutilisation of those that had been built. 
The reasons for this fairly consistent overprediction of airport and particularly runway requirements of the late-1970s and early-1980s are worth exploring in greater detail. Some of them are quite commonly understood, while others are not.

A first reason for overprediction was that airport planners of the late1960 s had projected forward the growth rates in passenger numbers of the 1960s in linear fashion. Actual growth in passenger numbers in the 1970s and early-1980s was not as dramatic as this extrapolation suggested. During the 1970s, passenger numbers both worldwide and in Sydney about doubled, in comparison with the trebling of the 1960s (see Tables 1 and 3 and Figures 1 and 3). In the early-1980s, in what was a major downturn for the aviation industry both worldwide and in Sydney, passenger numbers actually declined for a couple of years and by 1984 were only just recovering to their 1979/1980 levels (again, see Tables and Figures 1 and 3 ).

The second reason that the 1960s airport planners' overpredicted the airport needs of the late-1970s and early-1980s was their failure to foresee the extent of the impact of larger wide bodied aircraft on the practices of commercial air carriers, and hence on aircraft movement numbers. In worldwide terms, numbers of scheduled aircraft movements of commercial air carriers virtually remained static from 1973 to 1983 (see Table 2 and Figure 2). In Sydney, international aircraft movements went from 15,000 in 1970 to 20,000 in 1978 and then actually fell slightly; not recovering to their 1978 level until 1985. Interstate aircraft movements at KSA peaked at around 63,000 in 1974 and then gradually fell back to as low as 46,000 in the slump of the early-1980s (see Table 4 and Figure 4). In short, the number of aircraft movements in these two major industry sectors at KSA was static or even in decline for over a decade, although passenger numbers were slowly increasing.

A third reason for the 1960s overprediction of airport and particularly runway needs of the late-1970s and early-1980s has to do with the nature of runway capacity. Official measures of runway capacity are not absolute. Rather they take existing aircraft mixes and daily peak-usage patterns and derive an 'attainable' daily and annual capacity by projecting these patterns forward to larger numbers of aircraft movements. In reality, as larger 
numbers of aircraft movements do eventuate, aircraft mixes are likely to change, daily peaking patterns are likely to spread and attainable capacity is likely to increase. This can happen both as a result of changes in airport user behaviour and can be further enhanced by airport management changes-such as the introduction of peak period landing price surcharges as occurred in London from the mid-1970s. The officially given 'annual attainable runway capacity' for the two London airports at Gatwick and Heathrow increased from 315,000 aircraft movement in 1963, to approximately 350,000 in 1967 , to 480,000 in 1971 and 600,000 by the mid-1970s. 6 KSA, by comparison, increased it annual attainable runway capacity from 180,000 aircraft movements in the early-1970s, to 190,000 in the late-1970s, to 203,000 in $1983-84$. If we compare these changing official estimates runway of capacity to total numbers of aircraft movements actually occurring at KSA (given in the right hand column of Table 4), it is evident that annual attainable runway capacity at KSA during this time continually expanded to 20,000 or more greater than actual annual aircraft movement numbers. Aviation experts working on airport planning for Sydney and other cities around the world had not predicted such an expansion in attainable runway capacity and hence had over-estimated runway needs.

Once these three aspects of the overprediction of airport requirements for the late-1970s and early-1980s are appreciated, one of the unacknowledged successes of policy-making for Sydney's airport needs during these years has to be that successive federal governments did not get caught in the rush to construct airport facilities, and particularly runways, earlier than they were in fact required. Both the Whitlam and the Fraser government's were in retrospect lucky not to have proceeded with further airport construction too early. Procrastination during these years certainly had its benefits, and decisive support for airport construction certainly had its costs; as those involved in the Montreal, Tokyo and Paris cases were soon learning. This analysis is at odds with the common interpretation that a more successful policy-making outcome in the Sydney case would have been to have built the third runway some years ago.

6 Peter Hall, Great Planning Disasters, University of California Press, Berkeley \& Los Angeles, 1980, p23. 


\section{THE GROWTH OF SYDNEY'S INTRA-STATE COMMUTER SECTOR AND Changing RUNWAY UTILISATION AT KSA}

The aviation industry operating out of KSA comprises not only international and interstate operators, but also intra-state scheduled services and non-scheduled general aviation. In the 1960 s, the intra-state sector of the Sydney aviation industry was dominated by two airlines, East West and Air NSW. Each was licensed by the NSW State government to provide a monopoly service on approximately 50 per cent of state's recognised network of intra-state air routes. This network served almost 50 country centres, some individually and some as part of multi-hop services. From the late-1960s, however, the two intra-state airlines began to withdraw services from a number of these centres, arguing that the services were no longer economically viable given the new types of planes with which the two airlines were now operating and the cessation of earlier federal government subsidies for the development of rural air routes. In the wake of these withdrawals, smaller operators applied to the NSW government to licence 'commuter' services using smaller aircraft between unserviced country centres and Sydney. The NSW government generally acceded to these licensing requests and thus was created a new element of the Sydneybased aviation industry which came in time to be known as the 'intra-state commuter' sector.

The growth of this new intra-state commuter sector at KSA during the 1970s and early-1980s was both spectacular and in marked contrast to the contemporary slow down in the larger international and interstate sectors of the industry. By 1976, when the intra-state sector was first fully separated into its 'commuter' and 'regional' components for statistical purposes, the commuter sector was already accounting for 22,000 aircraft movements per annum at KSA; i.e., almost as many movements as the intra-state regional sector's 26,000 and more movements than the international sector's 19,000 (see Table 4 and Figure 4). The commuter sector in 1976 was, however, only carrying about 127,000 passengers compared with the intra-state regional sector's 829,000 (see Table 3 and Figure 3). By 1982, at the height of its development, the commuter sector was generating an expanded 45,000 aircraft movements per annum at KSA and carrying 327,000 passengers compared with the intra-state regional sector's fairly 
constant 24,000 movements and 747,000 passengers (again,see Tables and Figures 3 and 4).

In summary, during the 1970 s and early-1980s, the intra-state portion of Sydney's aviation industry, through the commuter service explosion, produced a rapidly increasing number of aircraft movements at KSA but did not greatly expand its total passenger load. The large international and interstate carriers were, by contrast, through the introduction of widebodied aircraft, gradually carrying more passengers with a fairly constant, even slightly declining, number of aircraft movements. If we add to this a slowly increasing number of non-scheduled general aviation movements (see Table and Figure 4), then runway utilisation patterns at KSA during these years can be seen to have been changing dramatically. More smaller planes were sharing available runway space with a fairly constant number of larger planes.

\section{The EMERgence OF TRAFFiC MANAGEMENT AND PRICING MEASURES AS SUGGESTED SOLUTIONS TO AIRPORT CAPACITY PROBLEMS}

When governments around the world in the early-1970s failed to back many of the airport and runway construction plans of their aviation authorities, some of these authorities began investigating other 'nonconstruction' ways of addressing airport capacity and congestion problems. As mentioned earlier, the British airport authorities introduced a peakperiod pricing surcharge at London airports from the mid-1970s. In Australia, the Commonwealth aviation authorities responded to the Whitlam government's decision to build a second airport at Galston instead of a third runway at KSA by arguing that they could handle all aircraft movements at KSA until 1990 without further runway construction if certain traffic management and pricing measures were introduced. These included the exclusion or limitation of access of certain small types of aircraft, the abandonment of preferred noise-reducing runway utilisation patterns and the introduction of peak-period pricing. These measures were further discussed in relation to the Sydney case during the late-1970s, but not taken further. By the beginning of the 1980 s, some professional economists were starting to advocate such non-construction measures more 
strongly, particularly to cope with the proliferation of small plane runway users at KSA. ${ }^{7}$ This new pattern of runway utilisation at KSA was criticised by these economists as an inefficient use of an expensive public facility, especially during peak hours of demand. The Sydney Morning Herald gave considerable support to these traffic management and pricing ideas as ways of catering for Sydney's future airport needs. Indeed, in October 1982 when the Fraser Coalition government announced that it was finally going to proceed with the construction of a third runway at KSA, the Herald's editors were surprisingly critical. They argued that such a runway was not necessary and merely represented an increased public subsidy to an already heavily-subsidised aviation industry. What was needed, they argued, was a more efficient traffic management and pricing system which would somehow encourage a rationalisation of the recent proliferation of small plane users at KSA, particularly during peak hours. ${ }^{8}$

Such suggestions for an alternative non-construction approach to Sydney's airport needs in the late-1970s and early-1980s did not meet with much acceptance either among the aviation industry or among the Commonwealth aviation authorities. Aviation and other interests in country NSW saw such ideas as highly inequitable and totally unacceptable. They saw them as discriminating strongly against air travellers from country NSW in favour of their overseas and interstate counterparts, and argued strongly that country travellers had as much right of access to KSA as did anyone else. The international and interstate sectors of the aviation industry at KSA, while not so actively hostile to these traffic management and pricing ideas, were happy enough with the status quo. These sectors were not greatly increasing their own runway usage at KSA at the time and did not, therefore, see competing smaller runway users as much of a problem.

7 See Gordon Mills in Sydney Morning Herald, 11-13/2/1980, and Investment in Airport Capacity-A Critical Review of the Mans Study, Department of Economics University of Sydney, Working Paper No 55. See also P.J. Forsyth 'Airport Runway Capacity in the Sydney Region: The Problems of Allocation and Expansion', in Christopher Findlay, et al., Changes in the Air? Issues in Domestic Aviation Policy, Centre for Independent Studies, St Leonards, NSW, 1984.

8 See Editorial in Sydney Morning Herald, 8/10/82 and Gittins in Sydney Morning Herald, 11/10/82. 
The federal aviation authorities were also unconvinced of the wisdom of these alternative non-construction approaches to Sydney's airport needs. In the past, these aviation authorities had adopted a fairly passive nondirective approach to traffic management and a very non-demand-conscious approach to the charging of airport users. Small aircraft paid only an annual fee for the use of the airport and larger aircraft a weight related landing charge. All scheduling and other operational matters were left to aircraft operators with departing and arriving aircraft essentially handled on a first-come/first-served basis, and only minor priority being given to scheduled public transport services over non-scheduled general aviation. User demand was essentially seen by the federal aviation authorities as something that was to be responded to through the construction of additional facilities, rather than as something that could be significantly altered or directed through traffic management or pricing measures. A third runway at KSA was still the preferred approach to providing for Sydney's future airport needs and, despite the downturn in the major sectors of the industry during the early-1980s, the federal aviation authorities were more than willing to accept the Fraser government's support for such a runway when it was finally forthcoming in late 1982. While the economists and the Sydney Morning Herald had identified the increase in small aircraft usage of KSA's runway capacity as inefficient and had suggested some alternative non-construction remedies for it, the industry, the aviation authorities and country NSW travellers were at this stage not yet interested in such an approach.

THE AVIATION INDUSTRY'S RESURGENCE OF THE MID-1980S AND THE RE-EMERGENCE OF THE AIRPORT DEVELOPMENT ISSUE.

When the Hawke Commonwealth Labor government came to power in Australia in March 1983, the major commercial sectors of the aviation industry, both in Sydney and worldwide, were still in the depths of their major downturn. The new government addressed the Sydney airport issue as much out of tradition and in response to the Fraser government's recent third runway commitment as through any pressing need for new airport facilities. The second Sydney airport site selection program, conducted by the Hawke government over its first two and a half years in office, was 
notable for its lack of a sense of urgency about further development of Sydney's airport facilities. A second airport site was being selected mainly as a way of bringing uncertainty over location to an end and as a way of preempting further urban development of potential sites. Indeed, the lack of any sense of urgency in the airport policy-making process was evident as late as 1987, when the Hawke government was acquiring the nominated Badgery's Creek second airport site at a notably leisurely pace.

In the period since 1984, however, there had in fact been quite significant renewed growth in the large commercial sectors of the aviation industry, both worldwide and at KSA. Passenger movement numbers were growing steadily again after the plateau of the early-1980s (see Tables and Figures 1 and 3). More importantly, however, aircraft movement numbers were also growing again at rates which had not been seen since the 1960 s (see Tables and Figures 2 and 4). The effect of wide-bodied jet aircraft replacing smaller narrow-bodied aircraft was gradually coming to an end and more passengers did now mean more aircraft movements. It was probably only a matter of time, therefore, before airport development would become an issue of considerable public concern and old airport and runway construction plans would once again become revitalised. In late1987, Airports International magazine identified eleven large new airports 'in the pipeline', as well as some major upgradings at existing airports. Badgery's Creek was listed among these new airport proposals, as were others already at a much more advanced stage; such as Osaka's second airport to be operational about 1992, London's effective third airport being developed through the massive upgrading of Standsted, and new replacement airports for those previously serving Munich, Denver and Athens. Airports International regarded even these new airports and upgradings, however, as 'too little, too late', as too did others close to the airport industry. 9

The catalyst for bringing the airport development issue back to public prominence in Sydney seems to have been the coming of Australia's bicentennial celebrations in 1988, and the international tourist boom which

9 See 'World Development Survey - Too Little, Too Late' , Airports International December $87 /$ January 88 and Editorial Airports International, November 1987. See also 'Editorial-Who speaks out in favour of more airports?', Airport Forum May 1988. 
accompanied them. Within three months of the Australia Day celebrations in Sydney in January 1988, the Australian newspaper had devoted no less than three editorials to the Sydney airport issue, arguing that not only did the international terminal at KSA need upgrading and expansion, but that the time had come for the late-night curfew on jet aircraft to be relaxed and for construction of a third runway at KSA to proceed.10 Other media commentary also saw KSA as having reached a runway and terminal capacity crisis.

The Hawke government's responses to these renewed perceptions of an urgent airport problem in Sydney in 1988 were numerous and far reaching. In March, it directed a Senate Committee to examine the 'adequacy of international terminal and aircraft handling facilities' at KSA.11 In April, in conjunction with the newly-elected NSW State Liberal government, it established another joint commonwealth/state task force to look both at the 'optimum utilisation of existing airports' and at 'the medium and longer term phased development and utilisation of airports' in the Sydney region. ${ }^{12}$ From June until August, the Commonwealth government also became involved in a process of negotiation with local councils in the area around KSA over proposed relaxation of the late night curfew on jet aircraft movements, settling finally on a lesser relaxation than that initially proposed.13 In September, it announced the go-ahead for major expansion plans for the international terminal at KSA. Then, in November, it received the report of the joint commonwealth/state task force.

Throughout 1988, the Hawke government strongly maintained its opposition to the construction of a third runway at KSA, arguing instead that the development of the second airport at Badgery's Creek could be accelerated if necessary. The joint commonwealth/state task force did not, however, strongly back the Labor Commonwealth government in this policy stance. Their November 1988 report argued that the views of those

10 See Australian 16/2/88, 22/2/88 and 13/4/88.

11 See Senate Standing Committee on Transport, Communications and Infrastructure, The Adequacy of International Terminal and Aircraft Handling Facilities at Sydney Airport, December 1988.

12 See Report of the Joint Commonwealth/New South Wales Government Task Force, The Airport Needs of the Sydney Basin, November 1988.

13 See Minister for Transport and Communications, Senator Gareth Evans QC, Media Statement - Noise Reduction Strategy for Kingsford Smith Airport, 19 August 1988. 
supporting further runway development at KSA should be considered, and the report had done so. The possibility of reconsidering the no-thirdrunway line had now been broached, and from there, as we saw at the outset, pressures quickly mounted until Labor's no-third-runway policy was finally overturned in March 1989.

\section{The Runway Capacity Problem in the late-1980S: HoW URGENT IS THE NEED FOR CONSTRUCTION?}

Having broadly traced the history of airport policy-making both in Sydney and worldwide from the beginning of the jet age to the present, I turn in this final section to a more evaluative assessment of the present need for runway construction at KSA. Observing the stridency of calls for further runway development at KSA early in 1989, one might reasonably have concluded that the success of governments of the 1970s and early1980s in not constructing additional runway capacity for Sydney too early had soured by the late-1980s to a failure to construct it early enough. One could even be forgiven for believing that the existing two runways at KSA might physically not be able to handle the numbers of aircraft movements likely to be received in Sydney, either at present or over the next few years. Such is not the case.

The runway capacity problem at KSA, as at other airports around the world, has always been one of peak-period congestion, rather than of any ultimate lack of capacity. Theoretically, with its existing two runways and existing traffic control procedures, KSA could cater for as many as 340,000 aircraft movements in a year, even without breaking the old 7-hour latenight curfew period (i.e., 55 movements per hour multiplied by 17 hours per day and 365 days per year). That, of course, is an unrealistic figure as a practical measure of runway capacity. No airport is likely to run at its sustainable hourly capacity all day long and all year long. However, the question must remain as to how much further towards that theoretical figure KSA's attainable capacity for its existing runways can still move. From 1984 to early 1989 official estimates of KSA's annual attainable runway capacity rose from 203,000 to 224,000 . This latest capacity is still 17,000 ahead of the 207,000 aircraft movements actually experienced in 
1988 and over one-third greater than the official estimates of runway capacity which were being given in the early-1970s.

Past increases in runway capacity at KSA have been achieved almost entirely without resort to the sorts of traffic management and pricing measures long advocated by professional economists and adopted, to greater and lesser extents, at busy airports elsewhere around the world. However, peak-hour and indeed peak-minute congestion at KSA has increased to such an extent in recent years that the Australian aviation authorities have begun recently to reconsider these non-construction runway-capacity-increasing measures.

In 1987 the federal aviation authorities introduced a weight-related landing charge for light general aviation users which supplemented the former annual user fee, thereby bringing the charging of the general aviation sector more into line with that applied to other parts of the industry. In early-1989, a peak-period minimum landing charge of $\$ 200$ was imposed on general aviation users at KSA, considerably increasing the landing charge small general aviation users at KSA would have to pay during these hours as compared to outside them. This move by the federal aviation authorities was intended to discourage non-scheduled small plane users from landing at KSA during peak hours. However, in deference to intra-state sensitivities about access to KSA from country NSW, the new peak-period minimum landing charge was not at that stage applied to scheduled commuter service operators. These latter still pay the same weight-related landing charge whatever time of day they arrive at KSA. However, the imposition of a peak-period minimum charge on these operators is now also being considered as part of a major new traffic management and pricing review.

In their media release of 22nd March 1989, the Prime Minister and Minister for Transport and Communications, as well as announcing the goahead for a third runway subject to normal environmental impact assessment, also announced that new traffic management measures would be implemented at KSA within the next few months. These would be designed to reduce general aviation traffic at KSA during peak hours and to alleviate the problems caused by 'cluster scheduling' of aircraft arrivals and departures by domestic airlines. As a first step towards such traffic 
management changes, the Commonwealth Department of Transport and Communications produced a discussion paper in July 1989 outlining a proposed two-phase introduction of a new traffic management regime at KSA. 14 The first phase would include the introduction of a minimum peak period landing charge for all aircraft during the designated peak hours, including commuter operators. The second phase, to come into operation at the same time as deregulation of the two-airline interstate sector of the Australian aviation industry at the end of 1990, would comprise a 'comprehensive slot management regime'.

To explain the jargon of this second phase of the proposed new KSA traffic management regime, it needs to be recalled that all scheduling matters at KSA have until now been left entirely to the airlines. Popular times within peak hours, such as 9 am, effectively have far more flights scheduled for arrival or departure than can possibly be handled by the airport. These are the peak minutes within the peak hours, and at these times substantial delay is not only likely, but inevitable. Such delay is to some extent avoidable, if the number of departures and landings within a given time period is regulated to a sustainable level through the allocation of schedule slots. Such systems of 'slot allocation' have been in existence in New York airports since 1969 and have in recent years come to be widely used during peak periods at other busy airports in the United States and elsewhere. They have considerable potential for alleviating the worst aspects of 'peak minute' congestion at busy airports, thereby rendering the peak hours considerably more orderly.

In Sydney, during periods of bad weather, a voluntary slot allocation system has in fact been organised by the airline operators themselves for several years. However, phase two of this new proposed traffic management regime for KSA would make slot allocation the normal peakperiod traffic management practice, rather than just a device for coping with adverse weather conditions. The proposed system would allocate numbers of slots in each half hour period to the major runway user groups; so many to international, interstate and intra-state users. Allocation of slots to individual users within these major user groups would then be made by either an administrative or a market mechanism. The system would aim to

14 Department of Transport and Communications, Review of Traffic Management Arrangements at Sydney (Kingsford-Smith) Airport, Discussion Paper July 1989. 
maintain some degree of access for all three types of runway user at all times. It would, therefore, have some potential to address the concerns voiced by aviation and other interests in country NSW for equitable access to KSA for intra-state travellers, while also promoting more efficient use of available runway capacity.

This proposed new traffic management regime for KSA has not been fully spelt out and its further development and implementation are far from a certainty. However, from the work done thus far, it is clear that there is still considerable potential for utilising the existing runways at KSA both more efficiently and in a way which provides equitable access to all categories of user. Procrastination over runway construction for Sydney may, even today, prove to have its benefits as well as its costs. The federal aviation authorities and the various sectors of the aviation industry may be induced to make better use of the existing runways at KSA than they have done in the past, particularly during peak hours. The present rather passive traffic management and pricing regime at KSA, may change for the better over the next few years in a way that it might not have changed were new runway construction about to be complete. No doubt the third runway will be well utilised when it is finished, but in the mean time there is little reason to despair. KSA can handle more traffic, if its existing runways are managed appropriately. 
Table 1: Worldwide PASSENGer Movements of COMMERCIAL AIR CARRIERS

\begin{tabular}{|c|c|c|c|c|}
\hline Year & $\begin{array}{l}\text { Passengers Carried } \\
\text { (Millions)(2) exc } \\
\text { USSR Scheduled } \\
\text { Services Only }\end{array}$ & $\begin{array}{c}\text { Annual Growth } \\
\operatorname{Rate}(\%)\end{array}$ & $\begin{array}{l}\text { Passengers Carried } \\
\text { (Millions)(1) inc } \\
\text { USSR Scheduled } \\
\text { Services Only }\end{array}$ & $\begin{array}{c}\text { Annual Growth } \\
\text { Rate }(\%)\end{array}$ \\
\hline 1945 & 9 & & & \\
\hline 1946 & 18 & 100 & & \\
\hline 1947 & 21 & 17 & & \\
\hline 1948 & 24 & 14 & & \\
\hline 1949 & 27 & 13 & & \\
\hline 1950 & 31 & 15 & & \\
\hline 1951 & 42 & 35 & & \\
\hline 1952 & 46 & 10 & & \\
\hline 1953 & 52 & 13 & & \\
\hline 1954 & 58 & 12 & & \\
\hline 1955 & 68 & 17 & & \\
\hline 1956 & 77 & 13 & & \\
\hline 1957 & 85 & 10 & & \\
\hline 1958 & 87 & 2 & & \\
\hline 1959 & 98 & 13 & & \\
\hline 1960 & 106 & 8 & & \\
\hline 1961 & 111 & 5 & & \\
\hline 1962 & 121 & 9 & & \\
\hline 1963 & 135 & 12 & & \\
\hline 1964 & 155 & 15 & & \\
\hline 1965 & 177 & 14 & & \\
\hline 1966 & 200 & 13 & & \\
\hline 1967 & 233 & 17 & & \\
\hline 1968 & 261 & 12 & & \\
\hline 1969 & 293 & 12 & & \\
\hline 1970 & 311 & 6 & & \\
\hline 1971 & 329 & 6 & & \\
\hline 1972 & 368 & 12 & & \\
\hline 1973 & 404 & 10 & 489 & \\
\hline 1974 & 424 & 5 & 514 & 5 \\
\hline 1975 & 434 & 2 & 534 & 4 \\
\hline 1976 & 475 & 9 & 576 & 8 \\
\hline 1977 & 517 & 9 & 610 & 6 \\
\hline 1978 & 587 & 14 & 679 & 11 \\
\hline 1979 & & & 754 & 11 \\
\hline 1980 & & & 748 & -1 \\
\hline 1981 & & & 749 & 0 \\
\hline 1982 & & & 759 & 1 \\
\hline 1983 & & & 798 & 5 \\
\hline 1984 & & & 847 & 6 \\
\hline 1985 & & & 898 & 6 \\
\hline 1986 & & & 958 & 7 \\
\hline 1987 & & & 1024 & 7 \\
\hline 1988 & & & 1076 & 5 \\
\hline
\end{tabular}

Sources: (1) International Civil Aviation Organisation, 'Civil Aviation Statistics of the World'; (2) International Air Transport Association, 'World Air Transport Statistics', various years. 
Table 2: WORLDWIDE AIRCRAFT DEPARTURES OF COMMERCIAL AIR CARRIERS

\begin{tabular}{|c|c|c|c|c|}
\hline Year & $\begin{array}{c}\text { Aircraft } \\
\text { Departures } \\
\text { (Millions)(1) } \\
\text { exc USSR } \\
\text { Scheduled } \\
\text { Services Only }\end{array}$ & $\begin{array}{l}\text { Annual } \\
\text { Growth } \\
\text { Rate }(\%)\end{array}$ & $\begin{array}{c}\text { Aircraft } \\
\text { Departures } \\
\text { (Millions)(2) } \\
\text { IATA Members Only } \\
\text { Scheduled and Non- } \\
\text { Scheduled Services }\end{array}$ & $\begin{array}{l}\text { Annual } \\
\text { Growth } \\
\text { Rate }(\%)\end{array}$ \\
\hline 1963 & & & 4.16 & \\
\hline 1964 & & & 4.21 & 1 \\
\hline 1965 & & & 4.67 & 11 \\
\hline 1966 & & & 4.90 & 5 \\
\hline 1967 & & & 5.64 & 15 \\
\hline 1968 & & & 6.03 & 7 \\
\hline 1969 & & & 6.31 & 5 \\
\hline 1970 & & & 6.29 & 0 \\
\hline 1971 & & & 6.30 & 0 \\
\hline 1972 & & & 6.71 & 7 \\
\hline 1973 & 9.89 & & 7.05 & 5 \\
\hline 1974 & 9.61 & -3 & 6.65 & -6 \\
\hline 1975 & 9.68 & 1 & 6.49 & -2 \\
\hline 1976 & 9.98 & 3 & 6.68 & 3 \\
\hline 1977 & 10.12 & 1 & 6.76 & 1 \\
\hline 1978 & 10.38 & 3 & 6.11 & -10 \\
\hline 1979 & 10.66 & 3 & 6.08 & 0 \\
\hline 1980 & 10.57 & -1 & 5.97 & -2 \\
\hline 1981 & 10.14 & -4 & 5.72 & -4 \\
\hline 1982 & 10.15 & 0 & 5.61 & -2 \\
\hline 1983 & 10.82 & 7 & 5.74 & 2 \\
\hline 1984 & 11.41 & 5 & 6.26 & 9 \\
\hline 1985 & 11.86 & 4 & 6.51 & 4 \\
\hline 1986 & 12.56 & 6 & 7.56 & 16 \\
\hline 1987 & 13.09 & 4 & 8.28 & 10 \\
\hline 1988 & 13.58 & 4 & 9.05 & 9 \\
\hline
\end{tabular}

Sources: (1) International Civil Aviation Organisation, 'Civil Aviation Statistics of the World'; (2) International Air Transport Association, 'World Air Transport Statistics', various years. 
Figure 1: WORLDWIDE PASSENGER MOVEMENTS OF COMMERCIAL AIR CARRIERS

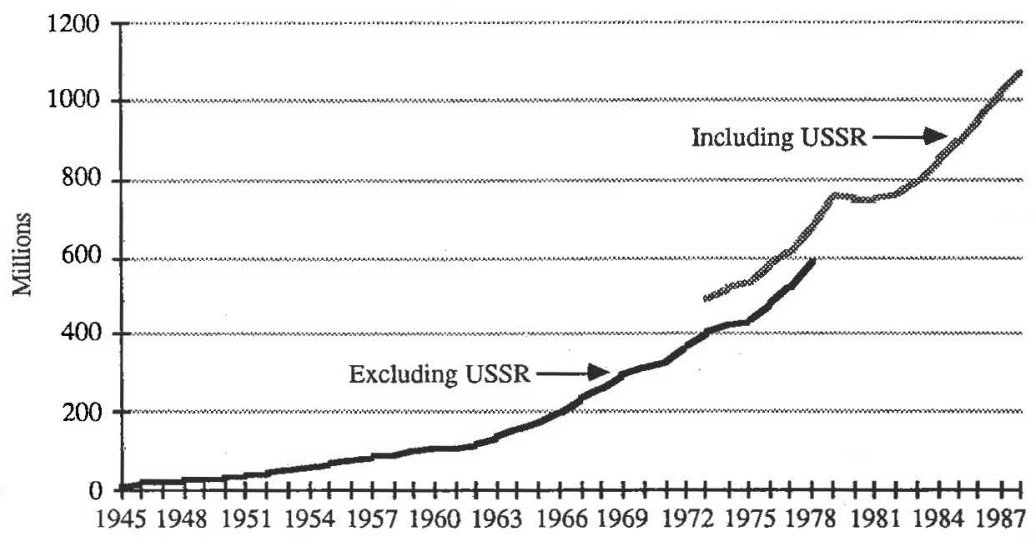

Figure 2: WORLDWIDE AIRCRAFT DEPARTURES OF COMMERCIAL AIR CARRIERS

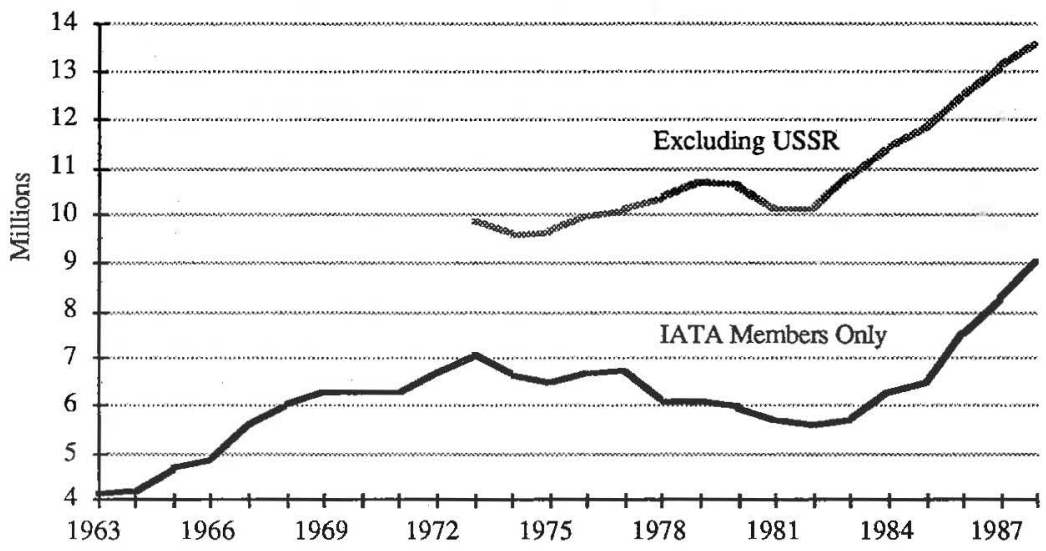


Table 3: KSA PASSEnger MOVEMENTS (MIllions)

\begin{tabular}{|c|c|c|c|c|c|}
\hline Year & International & & Domestic & & Total \\
\hline 1960 & 0.16 & & 1.46 & & 1.63 \\
\hline 1961 & 0.19 & & 1.49 & & 1.68 \\
\hline 1962 & 0.23 & & 1.51 & & 1.74 \\
\hline 1963 & 0.27 & & 1.67 & & 1.94 \\
\hline 1964 & 0.33 & & 1.95 & & 2.28 \\
\hline 1965 & 0.41 & & 2.21 & & 2.62 \\
\hline 1966 & 0.45 & & 2.30 & & 2.74 \\
\hline 1967 & 0.54 & & 2.54 & & 3.08 \\
\hline 1968 & 0.63 & & 2.76 & & 3.39 \\
\hline \multirow[t]{2}{*}{1969} & 0.74 & & 3.16 & & 3.90 \\
\hline & International & Interstate & $\begin{array}{c}\text { Intra-State } \\
\text { Regional }\end{array}$ & $\begin{array}{l}\text { Intra-State } \\
\text { Commuter }\end{array}$ & \\
\hline 1970 & 0.87 & 2.90 & 0.60 & 0.04 & 4.40 \\
\hline 1971 & 0.94 & 3.00 & 0.60 & 0.02 & 4.55 \\
\hline 1972 & 1.09 & 3.20 & 0.65 & 0.04 & 4.98 \\
\hline 1973 & 1.26 & 3.70 & 0.74 & 0.05 & 5.75 \\
\hline 1974 & 1.52 & 4.01 & 0.85 & 0.08 & 6.47 \\
\hline 1975 & 1.62 & 4.10 & 0.87 & 0.10 & 6.69 \\
\hline 1976 & 1.76 & 3.96 & 0.83 & 0.13 & 6.68 \\
\hline 1977 & 1.76 & 4.17 & 0.83 & 0.16 & 6.92 \\
\hline 1978 & 1.92 & 4.49 & 0.92 & 0.19 & 7.52 \\
\hline 1979 & 2.26 & 4.85 & 0.93 & 0.25 & 8.29 \\
\hline 1980 & 2.41 & 5.11 & 0.88 & 0.27 & 8.68 \\
\hline 1981 & 2.36 & 4.99 & 0.84 & 0.27 & 8.47 \\
\hline 1982 & 2.42 & 4.94 & 0.75 & 0.33 & 8.43 \\
\hline 1983 & 2.32 & 4.51 & 0.82 & 0.30 & 7.94 \\
\hline 1984 & 2.51 & 4.71 & 0.92 & 0.28 & 8.42 \\
\hline 1985 & 2.76 & 4.96 & 1.18 & 0.28 & 9.18 \\
\hline 1986 & 3.08 & 5.34 & 1.20 & 0.27 & 9.89 \\
\hline 1987 & 3.56 & 5.81 & 1.20 & 0.26 & 10.83 \\
\hline 1988 & 4.07 & 6.67 & 1.13 & 0.32 & 12.19 \\
\hline
\end{tabular}

Source: Department of Transport and Communications.

Note: International includes revenue passengers only. 
Table 4: KSA AIRCRAFT MOVEMENTS ('000S)

\begin{tabular}{|c|c|c|c|c|c|c|c|}
\hline Year & International & Interstat & & $\begin{array}{c}\text { Intra-State } \\
\text { Regional \& } \\
\text { Commuter }\end{array}$ & & $\begin{array}{c}\text { Non-Scheduled } \\
\text { General } \\
\text { Aviation } \\
\text { Services }\end{array}$ & $\begin{array}{l}\text { dotal } \\
\text { Fixed Wing } \\
\text { Aircraft } \\
\text { Movements }\end{array}$ \\
\hline $\begin{array}{l}1950 \\
1951 \\
1952 \\
1953 \\
1954 \\
1955 \\
1956 \\
1957 \\
1958 \\
1959 \\
1960 \\
1961 \\
1962 \\
1963 \\
1964 \\
1965 \\
1966 \\
1967 \\
1968 \\
1969 \\
1970 \\
1971 \\
1972 \\
1973 \\
1974 \\
1975\end{array}$ & $\begin{array}{r}4.8 \\
5.3 \\
5.8 \\
6.1 \\
6.9 \\
8.1 \\
8.2 \\
9.4 \\
10.4 \\
11.7 \\
14.5 \\
16.1 \\
17.1 \\
17.5 \\
18.5 \\
19.4\end{array}$ & $\begin{array}{l}43.8 \\
47.7 \\
49.6 \\
53.1 \\
52.7 \\
55.3 \\
59.2 \\
63.1 \\
61.1\end{array}$ & 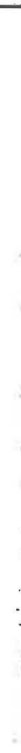 & $\begin{array}{l}20.2 \\
24.9 \\
28.2 \\
30.0 \\
27.1 \\
30.6 \\
33.5 \\
42.8 \\
46.2\end{array}$ & & $\begin{array}{l}26.3 \\
26.7 \\
28.2 \\
27.8 \\
27.2 \\
29.5 \\
26.9 \\
29.9 \\
29.3\end{array}$ & $\begin{array}{r}43.1 \\
51.5 \\
48.6 \\
50.4 \\
50.6 \\
60.3 \\
52.9 \\
52.6 \\
55.7 \\
57.1 \\
58.8 \\
65.1 \\
68.9 \\
73.5 \\
85.3 \\
93.6 \\
89.0 \\
99.7 \\
109.7 \\
117.7 \\
125.4 \\
123.1 \\
132.5 \\
137.1 \\
154.3 \\
156.0\end{array}$ \\
\hline 1975 & & & & $\begin{array}{l}\text { Regional } \\
\text { Only }\end{array}$ & $\begin{array}{c}\text { Commuter } \\
\text { Only }\end{array}$ & & \\
\hline $\begin{array}{l}1976 \\
1977 \\
1978 \\
1979 \\
1980 \\
1981 \\
1982 \\
1983 \\
1984 \\
1985 \\
1986 \\
1987 \\
1988\end{array}$ & $\begin{array}{l}19.5 \\
19.1 \\
20.2 \\
18.2 \\
18.5 \\
17.7 \\
18.6 \\
18.7 \\
19.6 \\
20.1 \\
22.0 \\
24.9 \\
28.0\end{array}$ & $\begin{array}{l}56.3 \\
57.7 \\
60.2 \\
59.2 \\
59.1 \\
55.0 \\
51.4 \\
46.9 \\
46.0 \\
49.6 \\
54.2 \\
60.0 \\
63.2\end{array}$ & & $\begin{array}{l}25.9 \\
26.0 \\
27.9 \\
28.4 \\
28.1 \\
26.4 \\
23.6 \\
24.7 \\
27.7 \\
31.4 \\
31.9 \\
32.5 \\
30.5\end{array}$ & $\begin{array}{l}21.6 \\
24.8 \\
28.1 \\
33.7 \\
35.6 \\
36.8 \\
45.2 \\
39.2 \\
33.6 \\
34.1 \\
33.2 \\
32.8 \\
39.3\end{array}$ & $\begin{array}{l}31.2 \\
32.7 \\
33.2 \\
40.2 \\
41.4 \\
42.3 \\
37.2 \\
38.4 \\
46.0 \\
48.7 \\
49.6 \\
48.0 \\
45.6\end{array}$ & $\begin{array}{l}154.6 \\
160.3 \\
169.7 \\
179.8 \\
182.7 \\
178.3 \\
176.0 \\
167.9 \\
172.9 \\
183.9 \\
190.9 \\
196.1 \\
206.7\end{array}$ \\
\hline
\end{tabular}

Source: Department of Transport and Communications. 
Figure 3: KSA PASSEnGER Movements

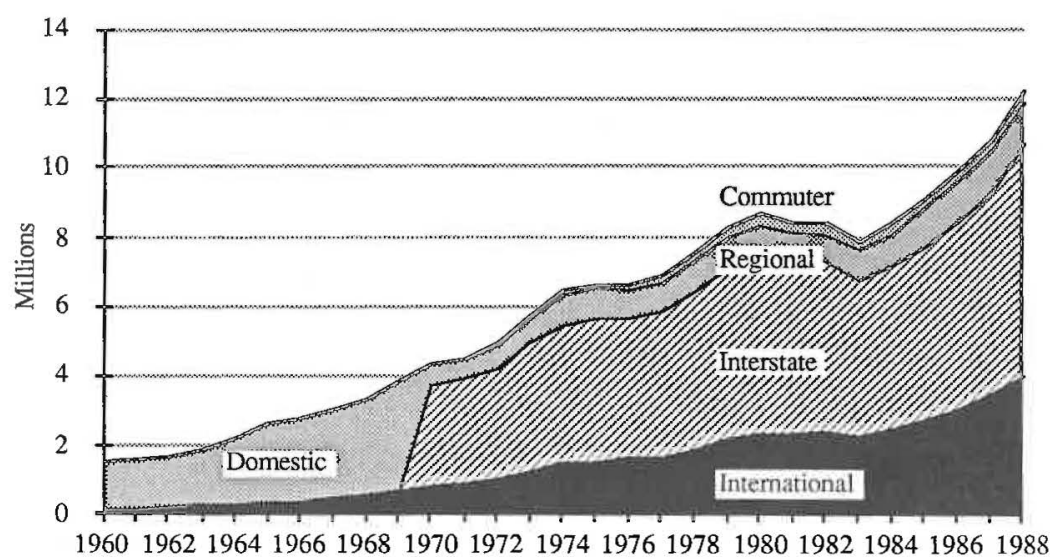

Figure 4: KSA AIRCRAFT MOVEMENTS

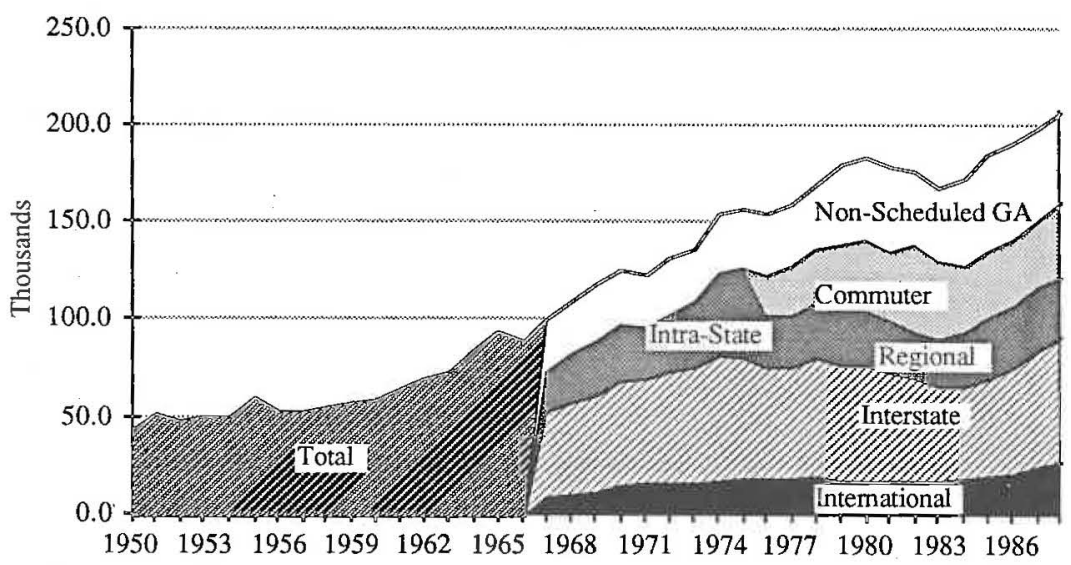




\section{UR U W O R K I N G PA P E R S \\ 1987-89}

No 1. Walker, Jill. Home-based Working in Australia: Issues \& Evidence. October 1987. [Out of Print]

No 2. Neilson, Lyndsay R. Metropolitan Planning in Australia: The Instruments of Planning - Regulation. April 1988. [Out of Print]

No 3. Neutze, Max. A Tale of Two Cities: Public Land Ownership in Canberra and Stockholm. May 1988. [Out of Print]

No 4. Troy, P. N. and C.J. Lloyd. 'Simply Washed Out by a Woman': Social Control, Status and Discrimination in a Statutory Authority. June 1988.

No 5. Wilmoth, David. Sydney's Metropolitan Strategy with A Comment by James R. Conner. June 1988. [Out of Print]

No 6. Metropolitan Planning in Australia: Urban Management. August 1988. [Papers by: M. Neutze, Planning as Urban Management: A Critical Assessment' and J. Mant, The Instruments of Planning: Urban Management'.] [Out of Print]

No 7. Self, Peter. Metropolitan Planning: An International Perspective. September 1988. [Out of Print]

No 8. Troy, P. N. and C.J. Lloyd. Industrial Organisation: Work Practices and Rituals in the Hunter District Water Board. December 1988. [Out of Print]

No 9. Howard, Michael. Advocacy and Resistance: The Question of a Post-War Commonwealth Government Role in Community Facilities, Town Planning and Regional Planning, 1939-52. December 1988. [Out of Print]

No 10. Badcock, Blair. Metropolitan Planning in South Australia. January 1989. [Out of Print]

No 11. Metropolitan Planning in Australia: Urban Consolidation. May 1989. [Papers by: R. Cardew, 'Urban Consolidation: A Comment on Prospects \& Policy'; P.N. Troy, 'Metropolitan Planning \& Urban Consolidation'; and R. Bunker, A Decade of Urban Consolidation'].

No 12. Bourassa, Steven. Postmodernism in Architecture and Planning: What Kind of Style? May 1989.

No 13. Bourassa, Steven. Land Value Taxation and Housing Development for Three Cities in Pennsylvania. June 1989.

No 14. Parkin, Andrew. Metropolitan Planning and Social Justice Strategies. August 1989.

No 15. Sawer, Marian. The Battle for the Family: Family Policy in Australian Electoral Politics in the 1980s. August 1989.

No 16. Neutze, Max and Kendig, Hal. Achievement of Home Ownership among PostWar Australian Cohorts. September 1989.

No 17. Dawkins, Jeremy. The Planning of Places Like Perth. October 1989.

No 18. O'Flanagan, Neil. The Sydney Harbour Trust: the Early Years. November 1989.

No 19. Smith, Susan J. Gender Differences in the Attainment and Experience of Owner-Occupation in Australia. December, 1989.

No 20. Sanders, Will. Policy-Making for Sydney's Airport Needs: A Comparative and Historical Perspective. December, 1989. 
